\title{
Perilaku sedentari sebagai faktor risiko kejadian obesitas pada anak sekolah dasar di Kota Yogyakarta dan Kabupaten Bantul
}

Andi Imam Arundhana', Hamam Hadi², Madarina Julia ${ }^{3}$

\begin{abstract}
Background: According to Basic Health Research (Riskesdas) 2010 the prevalence of obesity in Yogyakarta was $78 \%$ in 2010. Increasing prevalence of obesity in school children is mainly related to sedentary activities and decreasing medium-high physical activities.

Objective: To find out whether sedentary behavior was risk factor for obesity in school children and identify the level of its contribution.

Method: The study used case-control design. Population consisted of elementary school (either state or private) children of grade 1-5 at Yogyakarta and Bantul. The selection of school during screening phase was based on probability proportional to size (PPS) method. The choice of cases in children diagnosed obese during screening phase used simple random sampling supported with random table tool and matching of school. Based on sample basic calculation there were 488 samples consisting of 244 cases and 244 controls. Data of physical activities were obtained through modified questionnaire on children's physical activities (CPAQ). Data were processed using software of Epidata $v 3.1$ and STATA v.11. Analysis used univariate, bivariate, and multivariate analysis with $t$-test, anova, and logistic regression.

Result: Duration of sedentary behavior in obese students was longer than those not obese with average difference 49.81 minutes/day $(p<0.01)$. The result of Chi-square analysis showed sedentary activities had significant correlation with the incidence of obesity with $\mathrm{OR}=6.93$ (95\% Cl: 4.56-10.54). Based on types of sedentary activities, there was significant correlation for category of screen based and sitting around $(p<0.05)$.

Conclusion: Sedentary behavior was risk factor for the incidence of obesity in elementary school children. Average duration of sedentary activities of obese children was higher than those not obese. Based on residency, average duration of sedentary activities of obese children in urban area was higher than those living in rural area.
\end{abstract}

KEYWORDS: physical activities, overweight, rural, urban, elementary school children

\begin{abstract}
ABSTRAK
Latar belakang: Berdasarkan Riset Kesehatan Dasar (Riskesdas) tahun 2010, prevalensi obesitas di Yogyakarta adalah 78\% pada tahun 2010. Peningkatan prevalensi obesitas pada anak sekolah sangat berkaitan dengan aktivitas sedentari dan berkurangnya aktivitas fisik.

Tujuan: Untuk Mengetahui apakah perilaku sedentari merupakan faktor risiko terhadap obesitas anak sekolah dan mengidentifikasi seberapa besar kontribusinya.

Metode: Penelitian ini merupakan penelitian kasus kontrol. Populasi terdiri dari anak-anak sekolah dasar (baik negeri maupun swasta) kelas 1-5 di Yogyakarta dan Bantul. Pemilihan sekolah selama fase skrining berdasarkan metode probability proportional to size (PPS). Kasus adalah anak-anak yang didiagnosis obesitas pada saat fase skrining, menggunakan simple random sampling didukung dengan tabel random dan dilakukan matching pada sekolah tersebut. Berdasarkan perhitungan sampel, terdapat 488 sampel yang terdiri dari 244 kasus dan 244 kontrol. Data aktivitas fisik diperoleh menggunakan formulir CPAQ. Data diproses menggunakan Epidata v 3.1 and STATA v.11. Analisa data yang digunakan adalah univariat, bivariat, and analisa multivariat dengan t-test, anova, dan logistic regression.

Hasil: Durasi perilaku sedentari pada siswa obesitas lebih lama dibandingkan mereka yang tidak obesitas dengan ratarata perbedaan 49,81 menit/hari $(p<0,01)$. Hasil analisis Chi-square menunjukkan perilaku sedentari memiliki hubungan yang signifikan dengan kejadian obesitas dengan OR=6.93 (95\% Cl: 4,56-10,54). Berdasarkan jenis perilaku sedentari, terdapat hubungan yang signifikan untuk kategori screen based dan duduk-duduk $(p<0,05)$.

Kesimpulan: Perilaku sedentari merupakan faktor risiko terhadap kejadian obesitas pada anak-anak sekolah dasar. Rata-rata durasi perilaku sedentari pada anak yang obes lebih tinggi dibandingkan anak yang tidak obes. Berdasarkan tempat tinggal, rata-rata durasi perilaku sedentari pada anak obes di kota lebih tinggi dibandingkan yang di desa.
\end{abstract}

KATA KUNCI: aktivitas fisik, overweight, desa, kota, anak SD

${ }^{1}$ Pasca Sarjana Gizi dan Kesehatan Fakultas Kedokteran Universitas Gadjah Mada, Jl. Farmako, Sekip Utara Yogyakarta 55281. email: andiimam. arundhana@gmail.com

${ }^{2}$ Minat Utama Gizi dan Kesehatan, Fakultas Kedokteran Universitas Gadjah Mada. Jl. Farmako Sekip Utara, email: hamam@indosat.net.id

${ }^{3}$ Bagian anak RSUP Dr. Sardjito/Fakultas Kedokteran UGM. Jl. Kesehatan, Yogyakarta, email: madarinajulia@yahoo.com 


\section{PENDAHULUAN}

Menurut perkiraan dari The International Association for the Study of Obesity (IASO) dan International Obesity Task Force (IOTF) bahwa tidak kurang dari 200 juta anak usia sekolah di seluruh dunia telah kelebihan berat badan dan 40 hingga 50 juta di antaranya mengalami obesitas. Selain telah menjadi epidemi global, angka kejadian obesitas terus meningkat secara dramatis setiap tahunnya dalam satu dekade ini (1). Oleh karena itu, tidak heran jika saat ini obesitas pada anak telah dianggap sebagai krisis di seluruh dunia yang harus segera diatasi, tidak hanya karena dampak negatifnya terhadap kualitas hidup di usia dewasa, tetapi juga efek jangka pendeknya yang sangat merugikan anak-anak yang mengalaminya (2).

Beberapa penelitian yang dilakukan di negara-negara maju membuktikan bahwa obesitas pada masa anak-anak merupakan faktor yang dapat menurunkan usia harapan hidup. Penelitian-penelitian tersebut juga menunjukkan bahwa sebagian besar obesitas pada anak-anak berlanjut menjadi obes di usia remaja dan sebagian lagi akan berlanjut hingga dewasa (3). Hal ini berkaitan secara tidak langsung dengan masalah-masalah metabolik (4). Penelitian lain membuktikan hubungan yang bermakna antara kegemukan dengan dampak negatif terhadap harapan hidup seseorang. Individu yang sudah menjadi obes sejak kecil akan mempunyai risiko yang lebih besar (3).

Pada prinsipnya, obesitas terjadi sebagai hasil kronis dari kelebihan asupan energi yang berasal dari makanan dan minuman sedangkan keluaran energi kurang akibat gaya hidup yang kurang aktivitas. Kurang aktivitas fisik menyebabkan energi yang tidak digunakan akan tersimpan sebagai lemak di dalam jaringan adiposa. Selain faktor lingkungan, faktor sosiologis, fisiologis tubuh, perubahan metabolik dan neuroendokrin, serta herediter juga ikut terlibat namun dalam proporsi yang tidak dominan (5). Perilaku sedentari atau tidak beraktivitas fisik merupakan faktor risiko utama penyebab obesitas. Gaya hidup sedentari dan kurang aktivitas fisik terus meningkat sebagai akibat adanya transisi gaya hidup. Dahulu, segala aktivitas memerlukan tenaga fisik manusia dan kini semuanya dipermudah dengan bantuan teknologi (6). Penelitian lain menunjukkan bahwa faktor berdiam ini sangat besar pengaruhnya terhadap perkembangan obesitas dibanding makan berlebihan (7).

Jika di negara maju prevalensi obesitas pada anak sudah sangat tinggi, di negara berkembang pun prevalensi obesitas meningkat tiap tahunnya. Berbeda halnya di negara maju yang sedang memerangi obesitas, di negara berkembang masih belum siap karena menjadi beban ganda masalah gizi yaitu masih terdapatnya masalah gizi kurang/gizi buruk. Data di Indonesia tahun 2007, prevalensi obesitas pada anak umur 6-14 tahun mencapai $9,5 \%$ pada anak laki-laki dan $6,4 \%$ pada anak perempuan
(8). Angka ini naik pada tahun 2010 menjadi 10,7\% pada anak laki-laki dan $7,7 \%$ pada anak perempuan. Adapun prevalensi obesitas di Yogyakarta mencapai 7,8\% di tahun 2010 (9). Meningkatnya prevalensi obesitas pada anak salah satunya diprediksi karena perilaku sedentarian anak (10).

Di beberapa negara, perilaku sedentari saat ini menjadi isu penting dalam kesehatan masyarakat karena efek negatifnya terhadap kesehatan. Namun demikian, studi tentang perilaku sedentari ini di Indonesia masih kurang. Padahal aktivitas fisik pada anak-anak saja masih sangat kurang, apalagi aktivitas menetap/sedentari yang sering dilakukan anak-anak di waktu luang (11). Pada tingkat keseimbangan energi, defisit energi ekspenditur merupakan hasil dari kurangnya aktivitas fisik dan jika terjadi dalam waktu yang lama akan menyebabkan obesitas. Di Yogyakarta, kurang aktivitas fisik pada anakanak usia sekolah (10-14 tahun) sangat tinggi yakni mencapai $66,9 \%$ dan tidak ada lagi perbedaan kurang aktivitas fisik antara anak di daerah rural dan urban (8). Penelitian ini dilakukan untuk mengetahui apakah perilaku sedentari merupakan faktor risiko kejadian obesitas pada anak sekolah dasar di Kota Yogyakarta dan Kabupaten Bantul.

\section{BAHAN DAN METODE}

Penelitian ini merupakan penelitian kasus-kontrol yang dilakukan di Kota Yogyakarta dan Kabupaten Bantul. Penelitian ini merupakan bagian dari penelitian gabungan yang dilakukan oleh beberapa orang peneliti. Populasinya adalah siswa sekolah dasar (SD) kelas 1 sampai kelas $5 \mathrm{di}$ Kota Yogyakarta dan Kabupaten Bantul, baik yang berasal dari sekolah negeri maupun swasta yang tercatat di Dinas Pendidikan DIY. Penentuan sekolah terpilih untuk tahap skrining menggunakan metode probability proportional to size (PPS) (12). Metode PPS ini memerlukan data nama semua SD di Kota Yogyakarta dan Kabupaten Bantul serta jumlah kelas dan siswa dalam setiap kelasnya, lalu menggunakan interval untuk memilih kelas dari setiap SD yang terpilih sebagai subjek penelitian.

Pemilihan kasus diambil dari anak-anak yang didiagnosis obesitas pada tahap skrining menggunakan metode simple random sampling dibantu alat tabel random, sedangkan kontrol dipilih berdasarkan asal kelas dan sekolah yang sama dengan kasus serta orang tua menyetujui informed consent. Berdasarkan perhitungan besar sampel untuk studi kasus kontrol, digunakan nilai $\alpha=0,05$ dan $\beta=0,1$ karena kekuatan uji yang diinginkan adalah $90 \%$, besar sampel minimal yang dibutuhkan adalah 137 untuk setiap kelompok. Karena penelitian ini adalah penelitian gabungan, maka diambil besar sampel minimal terbesar yaitu 244 siswa untuk setiap kelompok dengan total sampel 488 siswa. Kriteria eksklusi sampel 
adalah siswa yang sedang duduk di kelas 6 pada saat pengambilan data dilakukan.

Jenis data yang dikumpulkan meliputi data karakteristik subjek penelitian menggunakan kuesioner terstruktur, data pola aktivitas fisik menggunakan kuesioner aktivitas fisik anak (CPAQ) yang sudah dimodifikasi. Data yang diperoleh kemudian diolah menggunakan software komputer dan dianalisis menggunakan statistik univariat, bivariat, dan multivariat. Data karakteristik dan aktivitas fisik diinput menggunakan Epidata versi 3.1 dan dianalisis menggunakan STATA v.11. Untuk melihat perbedaan durasi aktivitas sedentari dilakukan uji-t, dan untuk melihat besarnya risiko dilakukan analisis odds ratio (OR) dan Mc Nemar. Analisis Chi Square dilakukan untuk melihat perbedaan proporsi aktivitas fisik dan perilaku sedentari pada siswa obes dan tidak obes. Uji regresi logistik digunakan untuk menentukan faktor dominan yang mempengaruhi kejadian obesitas pada anak.

Penelitian ini telah mendapatkan persetujuan dan kelaikan penelitian dari Komite Etik Fakultas Kedokteran UGM tanggal 4 Maret 2013 Ref: KE/FK/199/EC. Penelitian ini juga menggunakan informed consent ketika meminta kesediaan responden untuk mau ikut serta sebagai subjek penelitian. Tim peneliti pada saat pengumpulan data di lapangan dibantu oleh enumerator dari mahasiswa gizi STIKES Alma Ata, Alumni DIII Gizi Poltekkes Yogyakarta dan Mahasiswa Prodi Gizi dan Kesehatan FK UGM Yogyakarta. Sebelum dilakukan pengambilan data, terlebih dahulu dilakukan pelatihan kepada calon enumerator, tujuannya untuk standardisasi proses pengambilan data di lapangan yang meliputi standardisasi pengukuran antropometri dan teknik wawancara untuk recall aktivitas, FFQ, dan kuesioner terstruktur. Penelitian ini dilakukan selama bulan November 2012 hingga Maret 2013.

\section{HASIL DAN BAHASAN}

Proporsi sekolah yang terpilih pada tahap skrining yaitu 32 sekolah di Yogyakarta dan 35 sekolah di Bantul. Skrining dilakukan untuk memperoleh data antropometri siswa-siswa di Yogyakarta dan Bantul. Dari hasil skrining tersebut, dipilih 244 siswa obes dan 244 siswa tidak obes (1:1) sehingga diperoleh jumlah subjek penelitian sebanyak 488 siswa. Pada penelitian ini dilakukan matching secara berpasangan asal sekolah dan kelas antara kelompok obes dan tidak obes.

\section{Karakteristik subjek penelitian}

Berdasarkan Tabel 1 diketahui bahwa terdapat perbedaan karakteristik antara dua kelompok subjek penelitian yakni variabel jenis kelamin dan kepemilikan kendaraan bermotor. Hal ini sejalan dengan penelitian yang juga membuktikan kelompok obes lebih banyak yang berjenis kelamin laki-laki dibandingkan perempuan (13,
14). Belum ada penjelasan yang lebih spesifik mengapa terjadi perbedaan antarjenis kelamin, namun diperkirakan perbedaan tersebut mungkin saja berkaitan dengan aktivitas berbasis layar seperti main game dan komputer. Anak laki-laki cenderung menyukai aktivitas berbasis layar seperti bermain game, game online, komputer, dan lain-lain dibandingkan dengan anak perempuan.

Berdasarkan sarana yang digunakan anak saat ke sekolah, anak yang diantar jemput ke sekolah dengan kendaraan bermotor lebih didominasi oleh anak obes $(64,75 \%)$. Penelitian school physical activity and nutrition (SPAN) menunjukkan proporsi menggunakan kendaraan untuk bepergian ke sekolah lebih tinggi pada anak obes dan yang tinggal di daerah urban (15). Anak yang tinggal di daerah rural masih cenderung menggunakan sepeda atau bahkan berjalan kaki ke sekolah.

Hasil penelitian ini tidak menunjukkan perbedaan yang siginifikan antara kelompok obes dan tidak obes untuk variabel sosial ekonomi seperti pendidikan dan pekerjaan orang tua, pendapatan keluarga, dan tempat tinggal. Hal ini semakin menguatkan teori bahwa sosial ekonomi merupakan akar masalah dari masalah gizi dan bukanlah sebagai faktor penyebab langsung. Jika seseorang meningkat sosial ekonominya maka akan meningkatkan faktor penyebab langsung obesitas, seperti meningkatkan konsumsi makanannya baik kualitas maupun kuantitas, menurunkan gerak tubuh seperti menggunakan kendaraan daripada jalan kaki (16). Selain itu, obesitas lebih banyak dipengaruhi oleh faktor lingkungan seperti asupan makanan dan aktivitas fisik $(16,17)$.

\section{Hubungan aktivitas fisik dengan obesitas}

Dalam penelitian ini tingkat aktivitas fisik dikategorikan dalam 4 tingkatan yaitu aktivitas sedentari, aktivitas ringan, aktivitas sedang, dan aktivitas berat. Tabel 2 menunjukkan sebagian besar siswa obes memiliki durasi aktivitas sedentari yang lebih dari 5 jam/hari, sedangkan siswa tidak obes sebagian besar durasi aktivitas sedentarinya kurang dari 5 jam/hari. Begitu juga terdapat perbedaan yang signifikan untuk aktivitas fisik sedang dan berat, namun tidak terdapat perbedaan yang siginifikan untuk aktivitas fisik ringan.

Aktivitas fisik merupakan faktor penyebab langsung obesitas dan faktor ini akan menjadi lebih besar jika dibarengi dengan pola makan yang tidak seimbang. Fisik yang kurang gerak menimbulkan gap antara energi yang masuk dengan energi yang keluar. Energi yang tidak digunakan akan disimpan di jaringan adiposa dalam bentuk lemak dan menyebabkan obesitas (18). Mengkonsumsi tambahan 100 kkal per hari akan menyebabkan sejumlah kecil kenaikan berat badan, namun kondisi ini perlu diperhatikan. Meskipun mengonsumsi makanan dalam jumlah yang sedikit, kebanyak obesitas terjadi karena ketidakseimbangan energi akut kecil (19). 
Tabel 1. Karakteristik subjek penelitian antara kelompok obes dan tidak obes

\begin{tabular}{|c|c|c|c|c|c|c|c|c|}
\hline \multirow{3}{*}{ Karakteristik } & \multicolumn{4}{|c|}{ Status obesitas } & \multirow{2}{*}{\multicolumn{2}{|c|}{ Total }} & \multirow{3}{*}{$\chi^{2}$} & \multirow{3}{*}{$\mathbf{p}$} \\
\hline & \multicolumn{2}{|c|}{ Ya } & \multicolumn{2}{|c|}{ Tidak } & & & & \\
\hline & $\mathbf{n}$ & $\%$ & $\mathbf{n}$ & $\%$ & $\mathbf{n}$ & $\%$ & & \\
\hline \multicolumn{9}{|l|}{ Kelompok usia } \\
\hline $6-8$ tahun & 84 & 34,43 & 83 & 34,02 & 167 & 34,22 & \multirow[t]{3}{*}{0,29} & \multirow[t]{3}{*}{0,86} \\
\hline 9-10 tahun & 114 & 46,72 & 119 & 48,77 & 233 & 47,75 & & \\
\hline $11-12$ tahun & 46 & 17,21 & 42 & 17,21 & 88 & 18,03 & & \\
\hline \multicolumn{9}{|l|}{ Jenis kelamin } \\
\hline Laki-laki & 154 & 63,11 & 122 & 50,00 & 276 & 56,56 & \multirow[t]{2}{*}{8,54} & \multirow[t]{2}{*}{0,003} \\
\hline Perempuan & 90 & 36,89 & 122 & 50,00 & 212 & 43,44 & & \\
\hline \multicolumn{9}{|l|}{ Kab/Kota } \\
\hline Yogyakarta & 166 & 68,03 & 166 & 68,03 & 332 & 68,03 & \multirow[t]{2}{*}{0,00} & \multirow[t]{2}{*}{1,00} \\
\hline Bantul & 78 & 31,97 & 78 & 31,97 & 156 & 31,97 & & \\
\hline \multicolumn{9}{|l|}{ Tempat tinggal } \\
\hline Kota besar & 13 & 5,33 & 19 & 7,79 & 32 & 6,56 & \multirow[t]{4}{*}{2,91} & \multirow[t]{4}{*}{0,40} \\
\hline Kota sedang & 34 & 13,93 & 43 & 17,62 & 77 & 15,78 & & \\
\hline Kota kecil & 174 & 71,31 & 163 & 66,80 & 337 & 69,06 & & \\
\hline Desa & 23 & 9,43 & 19 & 7,79 & 42 & 8,61 & & \\
\hline \multicolumn{9}{|l|}{ Pendidikan ibu } \\
\hline Tinggi & 200 & 81,97 & 191 & 78,28 & 391 & 80,12 & \multirow[t]{2}{*}{1,04} & \multirow[t]{2}{*}{0,30} \\
\hline Rendah & 44 & 18,03 & 53 & 21,72 & 97 & 19,88 & & \\
\hline \multicolumn{9}{|l|}{ Pekerjaan ibu } \\
\hline Tidak bekerja & 64 & 26,23 & 57 & 23,26 & 121 & 24,80 & \multirow[t]{2}{*}{0,53} & \multirow[t]{2}{*}{0,46} \\
\hline Bekerja & 180 & 73,77 & 187 & 76,64 & 367 & 75,20 & & \\
\hline \multicolumn{9}{|c|}{ Pendapatan keluarga } \\
\hline$\leq \mathrm{UMR}$ & 20 & 8,20 & 22 & 9,02 & 42 & 8,61 & \multirow[t]{2}{*}{0,10} & \multirow[t]{2}{*}{0,74} \\
\hline > UMR & 224 & 91,80 & 222 & 90,98 & 446 & 91,39 & & \\
\hline Jumlah ART & & & & & & & & \\
\hline$>4$ orang & 96 & 39,34 & 99 & 40,57 & 195 & 60,04 & 0,07 & 0,78 \\
\hline$\leq 4$ orang & 148 & 60,66 & 145 & 59,43 & 293 & 39,96 & & \\
\hline Kendaraan bermotc & & & & & & & & \\
\hline Ya & 158 & 64,75 & 136 & 55,74 & 294 & 60,25 & 4,14 & 0,04 \\
\hline Tidak & 86 & 35,25 & 108 & 44,26 & 194 & 39,75 & & \\
\hline
\end{tabular}

Tabel 2. Analisis Chi-Square hubungan durasi aktivitas fisik dengan obesitas

\begin{tabular}{|c|c|c|c|c|c|c|c|}
\hline \multirow{3}{*}{ Jenis aktivitas } & \multicolumn{4}{|c|}{ Status obesitas } & \multirow{3}{*}{$\chi^{2}$} & \multirow{3}{*}{$\mathbf{p}$} & \multirow{3}{*}{$\begin{array}{c}\text { OR } \\
(95 \% \mathrm{Cl})\end{array}$} \\
\hline & \multicolumn{2}{|c|}{ Ya } & \multicolumn{2}{|c|}{ Tidak } & & & \\
\hline & $\mathbf{n}$ & $\%$ & $\mathbf{n}$ & $\%$ & & & \\
\hline \multicolumn{8}{|l|}{ Sedentaria } \\
\hline$>5 \mathrm{jam} / \mathrm{hr}$ & 153 & 62,70 & 60 & 24,59 & 72,05 & $<0,001$ & 5,15 \\
\hline$\leq 5 \mathrm{jam} / \mathrm{hr}$ & 91 & 37,30 & 184 & 75,41 & & & $(3,42-7,76)$ \\
\hline \multicolumn{8}{|l|}{ Ringan $^{a}$} \\
\hline$>6 \mathrm{jam} / \mathrm{hr}$ & 134 & 54,92 & 139 & 56,97 & 0,20 & 0,648 & 0,92 \\
\hline$\leq 6 \mathrm{jam} / \mathrm{hr}$ & 110 & 45,08 & 105 & 43,03 & & & $(0,63-1,33)$ \\
\hline \multicolumn{8}{|l|}{ Sedanga } \\
\hline$\leq 3 \mathrm{jam} / \mathrm{hr}$ & 148 & 60,66 & 88 & 36,07 & 29,85 & $<0,001$ & 2,73 \\
\hline$>3 \mathrm{jam} / \mathrm{hr}$ & 96 & 39,34 & 156 & 63,93 & & & $(1,89-3,94)$ \\
\hline \multicolumn{8}{|l|}{ Berat $^{\mathrm{b}}$} \\
\hline$\leq 60$ menit/hr & 111 & 45,49 & 63 & 25,82 & 20,78 & $<0,001$ & 2,39 \\
\hline$>60$ menit/hr & 133 & 54,51 & 181 & 74,18 & & & $(1,63-3,51)$ \\
\hline
\end{tabular}

anilai rata-rata (dibulatkan); ${ }^{\mathrm{b}}$ Association for the study of obesity (ASO), 2012; 'Nilai median

Aktivitas fisik sedang dan berat berkaitan dengan total energi yang dikeluarkan, semakin rendah intensitas aktivitas fisik sedang dan berat, maka semakin sedikit pula energi ekspenditur. Association for the study of obesity merekomendasikan aktivitas fisik berat untuk anak dan remaja lebih dari 60 menit dalam sehari dan paling tidak 
dengan frekuensi 3 kali dalam seminggu (20). Penelitian yang dilakukan di Yogyakarta menyimpulkan bahwa subjek dengan IMT normal lebih banyak menggunakan waktunya untuk aktivitas di luar ruangan seperti berlari dan aktif bermain (7).

Penelitian ini melihat adanya perbedaan rasio sedentari dengan aktivitas sedang terhadap siswa obes dan tidak obes. Rasio ini lebih menggambarkan keseluruhan aktivitas yang dilakukan anak, misalnya untuk melihat apakah aktivitas sedang atau berat akan berpengaruh terhadap obesitas pada siswa dengan durasi perilaku sedentari yang sama. Hasil penelitian ini menunjukkan bahwa rasio perilaku sedentari terhadap aktivitas sedang dan berat di atas nilai median lebih banyak pada siswa obes, sedangkan yang berada di bawah nilai median lebih banyak pada siswa tidak obes. Hal ini berarti bahwa siswa obes memiliki kecenderungan durasi aktivitas sedentari yang lebih panjang dan aktivitas sedang-berat yang lebih sedikit dibandingkan siswa tidak obes. Penelitian lain yang sejalan dengan penelitian ini membuktikan bahwa remaja yang mempunyai rasio aktivitas ringan dan berat lebih dari median meningkatkan peluang 3,3 kali menjadi obes daripada lebih kecil dari nilai median (7).

\section{Durasi aktivitas fisik dengan obesitas}

Berdasarkan hasil uji-t pada Tabel 3, diperoleh data rata-rata durasi aktivitas sedentari dan ringan pada siswa obes lebih tinggi dibandingkan siswa tidak obes, sedangkan rata-rata durasi aktivitas sedang dan berat lebih tinggi pada siswa tidak obes. Hal ini sesuai dengan suatu penelitian bahwa jumlah menit dari aktivitas berat setiap harinya termasuk salah satu faktor yang mempengaruhi kejadian obesitas (21). Menurut penelitian di Amerika diketahui bahwa anak yang overweight cenderung memiliki tingkat keaktifan yang rendah dan juga memiliki perilaku sedentari yang tinggi (22). Hasil penelitian lain juga menemukan bahwa anakanak yang obes secara signifikan memiliki akumulasi total perhitungan accelerometerharian untuk aktivitas sedang dan aktivitas berat yang lebih rendah dibandingkan anak-anak yang tidak obes (23). Hal ini didukung pula dengan suatu penelitian yang menunjukkan bahwa siswa obes memiliki rata-rata durasi aktivitas sedentari 5,9 jam untuk yang obes, sedangkan yang normal 5,4 jam. Penelitian tersebut juga menyimpulkan jika terdapat efek independen dari aktivitas sedentari terhadap risiko kejadian obesitas (24).

Tabel 4 menunjukkan perbedaan bermakna durasi aktivitas antara siswa di Yogyakarta dan Bantul. Menurut penelitian yang dilakukan di Amerika, durasi aktivitas sedentari yang lebih lama didomimasi oleh anak yang tinggal di daerah urban. Anak yang tinggal di daerah rural masih cenderung menggunakan sepeda jalan kaki ketika ke sekolah (15). Sejalan dengan penelitian ini, penelitian lain yang dilakukan di Indonesia menunjukkan bahwa aktivitas fisik yang kurang cenderung terjadi di daerah perkotaan dan pada kelompok sosial ekonomi tinggi (25). Penelitian di Kota Makassar dan dari populasi sosial ekonomi menengah ke atas juga menunjukkan sebagian besar subjek penelitian, baik yang obesitas maupun tidak memiliki tingkat aktivitas

Tabel 3. Perbedaan rata-rata durasi aktivitas fisik kelompok obes dan tidak obes

\begin{tabular}{|c|c|c|c|c|}
\hline $\begin{array}{c}\text { Variabel } \\
\text { (menit/hari) }\end{array}$ & $\begin{array}{c}\text { Obes }(n=244) \\
\text { mean } \pm S D\end{array}$ & $\begin{array}{c}\text { Tdk obes }(n=244) \\
\text { mean } \pm S D\end{array}$ & $\begin{array}{l}\text { Mean diff. } \\
(95 \% \mathrm{Cl})\end{array}$ & $\mathbf{p}^{*}$ \\
\hline Perilaku sedentari & $315,06 \pm 48,72$ & $265,24 \pm 53,20$ & $\begin{array}{c}49,81 \\
(40,74-58,89)\end{array}$ & $<0,001$ \\
\hline Aktivitas ringan & $371,60 \pm 61,85$ & $367,96 \pm 59,12$ & $\begin{array}{c}3,63 \\
(-7,12-14,40)\end{array}$ & 0,25 \\
\hline Aktivitas sedang & $174,33 \pm 35,06$ & $195,31 \pm 37,09$ & $\begin{array}{c}20,97 \\
-27,39(-)-14,55\end{array}$ & $<0,001$ \\
\hline Aktivitas berat & $70,87 \pm 37,28$ & $91,18 \pm 42,00$ & $\begin{array}{c}20,31 \\
-27,37(-)-13,2\end{array}$ & $<0,001$ \\
\hline
\end{tabular}

$\mathrm{Cl}=$ confident interval $; \mathrm{SD}=$ Standar devasi; Mean diff.= perbedaan rata-rata ; ${ }^{*}$-test

Tabel 4. Perbedaan rata-rata durasi aktivitas fisik berdasarkan wilayah

\begin{tabular}{|c|c|c|c|c|}
\hline $\begin{array}{c}\text { Variabel } \\
\text { (menit/hari) }\end{array}$ & $\begin{array}{c}\text { Yogyakarta }(n=332) \\
\text { mean } \pm S D\end{array}$ & $\begin{array}{c}\text { Bantul }(n=156) \\
\text { mean } \pm S D\end{array}$ & $\begin{array}{l}\text { Mean diff. } \\
(95 \% \mathrm{Cl})\end{array}$ & $\mathbf{p}^{*}$ \\
\hline Perilaku sedentari & $294,40 \pm 56,94$ & $281,11 \pm 55,38$ & $\begin{array}{c}13,28 \\
(2,51-24,05)\end{array}$ & 0,007 \\
\hline Aktivitas ringan & $372,26 \pm 58,84$ & $364,49 \pm 63,67$ & $\begin{array}{c}7,77 \\
(-3,75-19,29)\end{array}$ & 0,09 \\
\hline Aktivitas sedang & $184,90 \pm 36,56$ & $184,65 \pm 39,69$ & $\begin{array}{c}0,24 \\
(-6,92-7,41)\end{array}$ & 0,47 \\
\hline Aktivitas berat & $80,79 \pm 40,89$ & $81,51 \pm 41,20$ & $\begin{array}{c}-0,72 \\
(-8,53-7,09)\end{array}$ & 0,57 \\
\hline
\end{tabular}

$\mathrm{Cl}=$ confident interval $; \mathrm{SD}=\mathrm{Standar}$ devasi; Mean diff.= perbedaan rata-rata; ${ }^{*}$ t-test 
fisik yang rendah (14). Tingginya tingkat sosial ekonomi berkaitan dengan pemenuhan berbagai fasilitas-fasilitas seperti kendaraan bermotor ataupun fasilitas elektronik yang membuat seseorang lebih banyak diam atau duduk memainkannya (16). Status social ekonomi maupun etnik berkorelasi positif dengan obesitas (26).

\section{Durasi aktivitas fisik berdasarkan status obesitas dan jenis kelamin}

Perbedaan durasi tiap jenis aktivitas ringan berdasarkan status obesitas maupun jenis kelamin dapat dilihat pada Tabel 5. Tidak ada perbedaan durasi aktivitas fisik ringan antara siswa obes dan tidak obes, karena pada dasarnya jenis-jenis aktivitas ringan tersebut merupakan aktivitas-aktivitas yang memang sebagian besar anakanak lakukan seperti belajar, kursus/mengaji, maupun bersih diri. Namun demikian, antaranak yang berbeda jenis kelaminnya, terdapat perbedaan untuk aktivitas membersihkan kamar dan mencuci. Kedua aktivitas ini memang lebih sering dilakukan oleh anak perempuan.

Pada Tabel 6 dapat dilihat perbedaan durasi tiap jenis aktivitas sedang berdasarkan status obesitas maupun jenis kelamin. Jenis aktivitas fisik sedang yang berbeda signifikan antara siswa obes dan tidak adalah menari, bermain tradisional, bulutangkis, dan olahraga lainnya. Telah terjadi transisi termasuk salah satunya perubahan pola permainan yang tadinya tradisional kini sudah banyak ditinggalkan dan tergantikan dengan permainan digital yang tidak perlu gerak untuk memainkannya (6). Terdapat perbedaan bermakna antarjenis kelamin untuk aktivitas pramuka, menari, dan bulutangkis.

Perbedaan durasi tiap jenis aktivitas berat berdasarkan status obesitas maupun jenis kelamin dapat dilihat pada Tabel 7. Terdapat perbedaan bermakna antara siswa obes dan tidak obes untuk aktivitas loncat tali, permainan tradisional lainnya, dan pelajaran olahraga. Dengan diketahuinya olahraga dan permainan tradisional berhubungan dengan obesitas, maka dapat dilakukan upaya intervensi untuk menurunkan obesitas pada anak. Penelitian lain membuktikan bahwa anak yang overweight cenderung memiliki tingkat keaktifan yang rendah dan juga memiliki perilaku sedentari yang tinggi. Saat ini anak-anak lebih tertarik ke aktivitas berbasis layar, daya tarik televisi, komputer untuk online, playstation, dan smartphone lebih tinggi daripada aktivitas bermain yang memerlukan keaktifan anak-anak seperti permainan tradisional dan permainan lainnya. Hal itu menyebabkan waktu anak-anak yang tersita untuk berdiam dan melakukan aktivitas berbasis layar lebih banyak dan waktu untuk aktivitas fisik lainnya berkurang $(22,27)$. Hasil penelitian ini juga sejalan dengan penelitian di Brazil yang membuktikan terdapat perbedaan intensitas dalam melakukan aktivitas fisik dan olahraga antar jenis kelamin (27).

Perbedaan durasi tiap jenis aktivitas sedentari berdasarkan status obesitas maupun jenis kelamin dapat dilihat pada Tabel 8. Hampir semua aktivitas berbasis layar berbeda secara signifikan antara siswa obes dan tidak obes. Pada dasarnya terdapat dua mekanisme utama pada kegiatan berbasis layar yang menjadi penyumbang terjadinya

Tabel 5. Jenis aktivitas fisik ringan berdasarkan status obes dan jenis kelamin

\begin{tabular}{lcccccc}
\hline \multirow{2}{*}{ Aktivitas fisik ringan } & \multicolumn{5}{c}{ Durasi (menit/minggu) } \\
\cline { 2 - 7 } & Obes & Tidak obes & \multirow{2}{*}{$\mathbf{p}^{*}$} & $\begin{array}{c}\text { Laki- } \\
\text { laki }\end{array}$ & Perempuan & $\mathbf{p}^{*}$ \\
\hline Bersih kamar & $26,8 \pm 46,7$ & $40,73 \pm 56,3$ & 0,99 & $26,7 \pm 47,1$ & $43 \pm 56,9$ & 0,0003 \\
Mencuci & $11,85 \pm 28,2$ & $16,0 \pm 29,1$ & 0,94 & $10,1 \pm 26,5$ & $18,8 \pm 30,7$ & 0,0004 \\
Bersih diri (mandi/pakaian) & $166,7 \pm 69,1$ & $173,8 \pm 59,9$ & 0,88 & $162,8 \pm 61,9$ & $179,4 \pm 67,1$ & 0,001 \\
Belajar/kerja tugas & $1912 \pm 317$ & $1867 \pm 298$ & 0,05 & $1887 \pm 345,8$ & $1893 \pm 252,7$ & 0,41 \\
Jalan kaki & $127,7 \pm 24,8$ & $131,6 \pm 30,2$ & 0,93 & $130,5 \pm 29,3$ & $128,5 \pm 25,4$ & 0,78 \\
Mengaji/kursus & $197,6 \pm 181$ & $206,5 \pm 173$ & 0,71 & $187,9 \pm 174$ & $220,5 \pm 180,5$ & 0,02 \\
Rekreasi & $45,5 \pm 55,8$ & $49,5 \pm 61,0$ & 0,77 & $48,8 \pm 57,1$ & $45,94 \pm 60,2$ & 0,70 \\
\hline
\end{tabular}

*uji-t

Tabel 6. Jenis aktivitas fisik sedang berdasarkan status obes dan jenis kelamin

\begin{tabular}{|c|c|c|c|c|c|c|}
\hline \multirow[b]{2}{*}{ Aktivitas fisik sedang } & \multicolumn{6}{|c|}{ Durasi (menit/minggu) } \\
\hline & Obes & Tidak obes & $\mathbf{p}^{*}$ & $\begin{array}{l}\text { Laki- } \\
\text { laki }\end{array}$ & Perempuan & $\mathbf{p}^{*}$ \\
\hline Ekstrakurikuler pramuka & $55,71 \pm 55,9$ & $50,3 \pm 42,05$ & 0,88 & $44,9 \pm 39,3$ & $63,5 \pm 58,6$ & $<0,001$ \\
\hline Ekstrakurikuler menari & $5,51 \pm 19,15$ & $10,5 \pm 24,6$ & 0,006 & $3,98 \pm 16,1$ & $13,25 \pm 27,3$ & $<0,001$ \\
\hline Ekstrakurikuler marching band & $4,42 \pm 22,3$ & $7,31 \pm 35,8$ & 0,14 & $5,54 \pm 31,5$ & $6,29 \pm 27,7$ & 0,39 \\
\hline Bermain (engklek, kasti, kelereng, ditaman, dII) & $69,68 \pm 104$ & $97,95 \pm 117,2$ & 0,002 & $84,61 \pm 77,9$ & $82,79 \pm 145$ & 0,57 \\
\hline Bulutangkis & $41,9 \pm 77,1$ & $73,91 \pm 121$ & $<0,001$ & $45,65 \pm 87,2$ & $73,89 \pm 118$ & 0,001 \\
\hline Lainnya (basket, tenis meja, memancing, dII) & $79,59 \pm 76,9$ & $122,5 \pm 118$ & $<0,001$ & $98,63 \pm 103$ & $104,2 \pm 101,5$ & 0,27 \\
\hline
\end{tabular}


obesitas, di antaranya penurunan energi ekspenditur akibat tergantinya waktu untuk melakukan aktivitas fisik sedang dan berat dengan aktivitas sedentari tersebut. Mekanisme kedua yaitu selama menonton televisi anak-anak akan terpapar iklan-iklan makanan yang tidak sehat (junk food) yang akan mempengaruhi pemilihan makanan anak $(7,28)$.

\section{Durasi dan frekuensi aktivitas sedentari berdasarkan tempat tinggal}

Pada Tabel 9 menunjukkan bahwa terdapat perbedaan durasi dan frekuensi untuk aktivitas screen based kecuali nonton TV. Hal ini mendukung asumsi bahwa perbedaan wilayah mempengaruhi akses terhadap berbagai fasilitas dan informasi. Di daerah Bantul masih jarang ditemukan warung internet, tempat bermain game online, playstation, dan para siswa jarang yang memiliki handphone, tablet, ataupun laptop, sedangkan di Yogyakarta akses terhadap media hiburan digital tersebut sangat mudah ditemukan. Anak-anak SD di Yogyakarta juga rata-rata memiliki handphone/tablet terutama di sekolah-sekolah unggulan.Tidak terdapatnya perbedaan untuk menonton TV karena saat ini TV telah menjadi barang rumah tangga primer yang hampir dimiliki setiap keluarga. Menurut survei di Amerika, sebagian besar penduduk memanfaatkan waktu luangnya untuk menonton televisi (29), padahal di Amerika Serikat dan kemungkinan besar di negara lain jumlah jam yang dihabiskan untuk menonton televisi, duduk, dan bermain game berhubungan dengan obesitas pada anak (25).

Tabel 7. Jenis aktivitas fisik berat berdasarkan status obes dan jenis kelamin

\begin{tabular}{|c|c|c|c|c|c|c|}
\hline \multirow{2}{*}{ Aktivitas fisik berat } & \multicolumn{6}{|c|}{ Durasi (menit/minggu) } \\
\hline & Obes & Tidak obes & $\mathbf{p}^{*}$ & Laki-laki & Perempuan & $\mathbf{p}^{*}$ \\
\hline Bersepeda & $182 \pm 165,8$ & $194,3 \pm 180,7$ & 0,21 & $181,9 \pm 165,7$ & $196,3 \pm 182,9$ & 0,18 \\
\hline Bermain sepak bola & $127,2 \pm 199,3$ & $149,3 \pm 209,8$ & 0,11 & $219 \pm 228,7$ & $33,18 \pm 94,4$ & $<0,001$ \\
\hline Loncat tali & $14,67 \pm 53,1$ & $41,37 \pm 94$ & $<0,001$ & $3,56 \pm 26,6$ & $59,8 \pm 105,4$ & $<0,001$ \\
\hline $\begin{array}{l}\text { Bermain (petak umpat, lari-larian, gobak sodor, } \\
\text { layangan, dll) }\end{array}$ & $90,62 \pm 113$ & $122,3 \pm 128$ & 0,001 & $103,3 \pm 92,6$ & $110,515,5$ & 0,25 \\
\hline $\begin{array}{l}\text { Pelajaran olahraga (berenang, fusal, tennis, karate, } \\
\text { silat) }\end{array}$ & $76,08 \pm 33,5$ & $82,648 \pm 50,9$ & 0,04 & $78,9 \pm 38,7$ & $79,9 \pm 48,4$ & 0,39 \\
\hline
\end{tabular}

*uji-t

Tabel 8. Jenis aktivitas fisik sedentari berdasarkan status obes dan jenis kelamin

\begin{tabular}{lcccccc}
\hline \multirow{2}{*}{\multicolumn{1}{c}{ Aktivitas sedentary }} & \multicolumn{4}{c}{ Durasi (menit/minggu) } \\
\cline { 2 - 6 } & Obes & Tidak obes & $\mathbf{p}^{*}$ & Laki-laki & Perempuan & $\mathbf{p}^{*}$ \\
\hline Nonton tv & $1070,5 \pm 346,55$ & $854,43 \pm 312,57$ & $<0,001$ & $959 \pm 362,2$ & $966,9 \pm 326,8$ & 0,59 \\
Video game & $76,77 \pm 135,51$ & $54,07 \pm 111,6$ & 0,02 & $92,2 \pm 149,7$ & $30,6 \pm 66,4$ & $<0,001$ \\
Komputer & $184,42 \pm 185,2$ & $146,80 \pm 168$ & 0,009 & $179,2 \pm 191,9$ & $148,4 \pm 155,9$ & 0,02 \\
HP/tablet/dll & $31,69 \pm 71,57$ & $23,47 \pm 51,42$ & 0,07 & $21,2 \pm 47,4$ & $35,8 \pm 76,9$ & 0,99 \\
Permainan papan & $66,96 \pm 120,16$ & $14,52 \pm 38,70$ & $<0,001$ & $39,9 \pm 97,7$ & $41,9 \pm 86,6$ & 0,43 \\
Permainan kartu & $13,81 \pm 49,98$ & $5,0 \pm 17,43$ & 0,004 & $10,0 \pm 43,9$ & $8,6 \pm 27,4$ & 0,34 \\
Membaca $_{\text {Makan }}^{240,85 \pm 200,6}$ & $243,43 \pm 187,8$ & 0,44 & $255,3 \pm 191,8$ & $263,8 \pm 195,1$ & 0,98 \\
Aktivitas duduk lainnya & $301,59 \pm 89,23$ & $310,24 \pm 99,82$ & 0,84 & $304,1 \pm 95,9$ & $308,2 \pm 93,2$ & 0,68 \\
\hline
\end{tabular}

* uji-t;

afrekuensi dinyatakan dalam kali/bulan

Tabel 9. Distribusi frekuensi dan durasi aktivitas sedentari berdasarkan wilayah

\begin{tabular}{|c|c|c|c|c|c|c|}
\hline \multirow{2}{*}{ Aktivitas sedentary } & \multicolumn{3}{|c|}{ Frekuensi (kali/minggu) } & \multicolumn{3}{|c|}{ Durasi (menit/minggu) } \\
\hline & Yogyakarta & Bantul & $\mathbf{p}^{*}$ & Yogyakarta & Bantul & $\mathbf{p}^{*}$ \\
\hline Nonton tv & $15,7 \pm 4,4$ & $16,3 \pm 4,28$ & 0,93 & $948,8 \pm 348,6$ & $991,6 \pm 342,5$ & 0,898 \\
\hline Video game & $1,5 \pm 2,2$ & $0,6 \pm 1,57$ & $<0,001$ & $81,0 \pm 137,8$ & $32,3 \pm 80,8$ & $<0,001$ \\
\hline Komputer & $3,9 \pm 3,7$ & $2,4 \pm 3,82$ & $<0,001$ & $192,0 \pm 180,4$ & $109,9 \pm 158,2$ & $<0,001$ \\
\hline HP/tablet/dll & $1,3 \pm 2,5$ & $0,8 \pm 1,97$ & 0,006 & $32,7 \pm 69,3$ & $16,6 \pm 42,3$ & 0,003 \\
\hline Permainan papan ${ }^{a}$ & $2,6 \pm 1,3$ & $2,8 \pm 1,40$ & 0,64 & $41,2 \pm 96,8$ & $39,7 \pm 84,5$ & 0,43 \\
\hline Permainan kartu ${ }^{a}$ & $0,8 \pm 0,8$ & $0,8 \pm 0,60$ & 0,47 & $9,0 \pm 40,2$ & $10,2 \pm 31,7$ & 0,61 \\
\hline Membaca & $3,9 \pm 3,0$ & $4,5 \pm 2,96$ & 0,96 & $221,6 \pm 187,6$ & $285,5 \pm 201$ & 0,99 \\
\hline Makan & $23,9 \pm 3,5$ & $24,3 \pm 3,01$ & 0,88 & $304,6 \pm 89,8$ & $308,8 \pm 104,5$ & 0,67 \\
\hline Aktivitas duduk lain & $31,5 \pm 5,2$ & $30,9 \pm 5,72$ & 0,11 & $3422 \pm 1178$ & $3204 \pm 1222$ & 0,02 \\
\hline
\end{tabular}

* uji-t; afrekuensi dinyatakan dalam kali/bulan 
Berdasarkan Gambar 1 dapat dilihat bahwa terdapat kecenderungan semakin lama aktivitas sedentari berbasis layar yang dilakukan, semakin tinggi risiko kejadian obesitas (hubungan positif).

Berdasarkan Gambar 1, anak dengan durasi menonton lebih dari 2 jam/hari memiliki risiko obesitas lebih tinggi dibandingkan dengan yang kurang dari 2 jam/ hari, namun anak dengan durasi lebih dari 4 jam/hari lebih berisiko lagi dibandingkan anak dengan durasi 2-4 jam/ hari. Sejalan dengan penelitian ini, di Amerika pada anak usia 8-16 tahun, prevelensi obesitas terendah pada anak yang menonton TV $<1$ jam per hari, dan tertinggi pada anak yang menonton TV >4 jam per hari (30). Di Amerika Serikat dan kemungkinan besar di negara lain jumlah jam yang dihabiskan untuk menonton televisi, duduk, dan bermain game berhubungan dengan obesitas pada anak (25).

\section{Analisis multivariat aktivitas sedentari dan obesitas dengan melibatkan variabel luar.}

Tabel 10 menjelaskan pengaruh variabel perilaku sedentari terhadap obesitas dengan mengontrol variabel

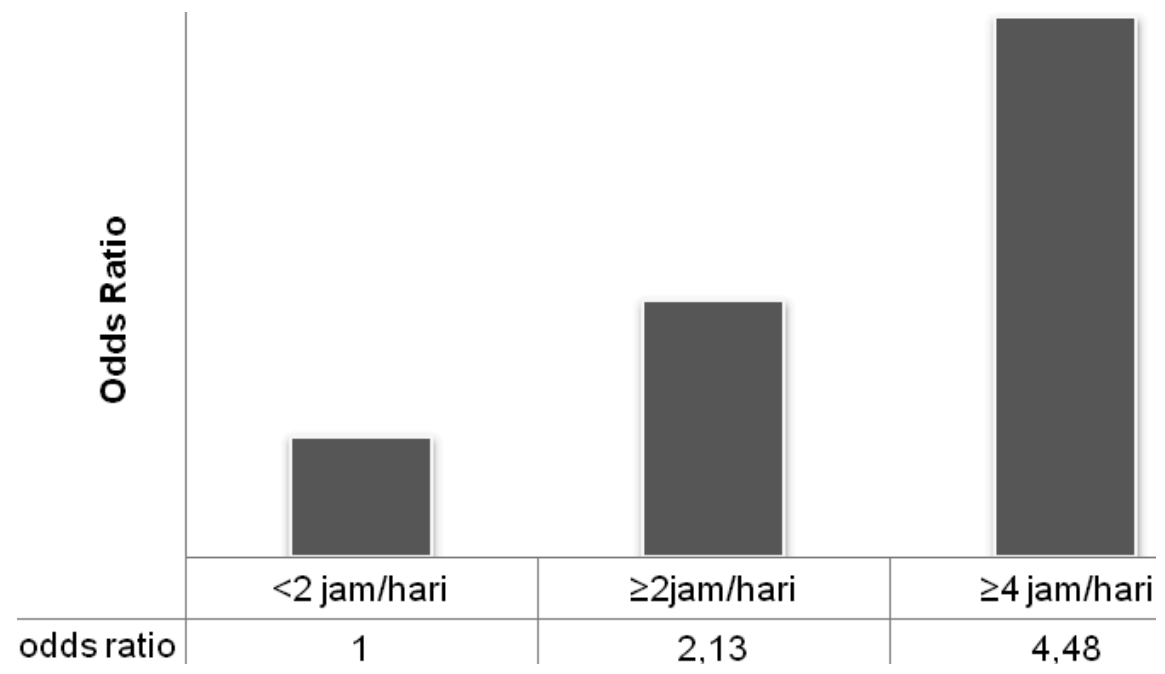

Gambar 1. Efek dosis aktivitas berbasis layar terhadap obesitas

Tabel 10. Faktor yang berpengaruh dominan terhadap kejadian obesitas berdasarkan model regresi logistik

\begin{tabular}{|c|c|c|c|c|c|c|}
\hline \multirow[t]{2}{*}{ Variabel } & \multicolumn{6}{|c|}{ Kejadian Obesitas } \\
\hline & Model 1 & Model 2a & Model $3^{b}$ & Model 4c & Model 5 & Model 6e \\
\hline & $\begin{array}{c}\text { OR } \\
95 \% \mathrm{Cl}\end{array}$ & $\begin{array}{c}\text { OR } \\
95 \% \mathrm{Cl}\end{array}$ & $\begin{array}{c}\text { OR } \\
95 \% \mathrm{Cl}\end{array}$ & $\begin{array}{c}\text { OR } \\
95 \% \mathrm{Cl}\end{array}$ & $\begin{array}{c}\text { OR } \\
95 \% \mathrm{Cl}\end{array}$ & $\begin{array}{c}\text { OR } \\
95 \% \mathrm{Cl}\end{array}$ \\
\hline \multicolumn{7}{|l|}{ Sedentari } \\
\hline $\begin{array}{l}\leq 5 \mathrm{jam} / \mathrm{hr} \\
>5 \mathrm{jam} / \mathrm{hr}\end{array}$ & $\begin{array}{c}5,15^{*} \\
(3,49-7,61)\end{array}$ & $\begin{array}{c}4,75^{\star} \\
(3,20-7,06)\end{array}$ & $\begin{array}{c}5,33^{*} \\
(3,58-7,39)\end{array}$ & $\begin{array}{c}5,30^{*} \\
(3,57-7,88)\end{array}$ & $\begin{array}{c}5,05^{*} \\
(3,40-7,50)\end{array}$ & $\begin{array}{c}4,90^{*} \\
(3,24-7,40)\end{array}$ \\
\hline \multicolumn{7}{|l|}{ Berat } \\
\hline $\begin{array}{l}\leq 60 \mathrm{mnt} / \mathrm{hr} \\
>60 \mathrm{mnt} / \mathrm{hr}\end{array}$ & & $\begin{array}{c}0,50^{*} \\
(0,33-0,75)\end{array}$ & & & & $\begin{array}{c}0,42^{*} \\
(0,27-0,65)\end{array}$ \\
\hline \multicolumn{7}{|l|}{ Jenis kelamin } \\
\hline $\begin{array}{l}\text { Perempuan } \\
\text { Laki-laki }\end{array}$ & & & $\begin{array}{c}1,86^{*} \\
(1,25-2,77)\end{array}$ & & & $\begin{array}{c}2,21^{*} \\
(1,46-3,35)\end{array}$ \\
\hline \multicolumn{7}{|l|}{ Wilayah } \\
\hline $\begin{array}{l}\text { Yogyakarta } \\
\text { Bantul }\end{array}$ & & & & $\begin{array}{c}1,25 \\
(0,82-1,90)\end{array}$ & & $\begin{array}{c}1,27 \\
(0,83-1,96)\end{array}$ \\
\hline \multicolumn{7}{|l|}{ Kepemilikan kendaraan } \\
\hline $\begin{array}{l}\text { Ya } \\
\text { Tidak }\end{array}$ & & & & & $\begin{array}{c}0,88 \\
(0,59-1,31)\end{array}$ & $\begin{array}{c}0,85 \\
(0,56-1,28)\end{array}$ \\
\hline $\mathrm{R}^{2}(\%)$ & 10,95 & 12,56 & 12,40 & 11,12 & 11,01 & 14,97 \\
\hline $\mathrm{n}$ & 488 & 488 & 488 & 488 & 488 & 488 \\
\hline -2 deviance likelihood & 602,42 & 591,56 & 592,60 & 601,26 & 602,04 & 575,26 \\
\hline
\end{tabular}

$\mathrm{n}=$ jumlah sampel; $\mathrm{OR}=$ odds ratio; $\mathrm{Cl}=$ confident interval; * $=$ signifikan

${ }^{a}$ variabel aktivitas sedentari terhadap obese dengan mengendalikan aktivitas berat; ${ }^{b}$ variabel aktivitas sedentari terhadap obese dengan mengendalikan jenis kelamin; 'variabel aktivitas sedentari terhadap obese dengan mengendalikan tempat tinggal; ${ }^{d}$ variabel aktivitas sedentari terhadap obese dengan mengendalikan variabel kepemilikan kendaraan; ' $v a r i a b e l$ aktivitas sedentari terhadap obese dengan mengendalikan semua variabel luar. 
luar, tujuannya untuk melihat sejauh mana seluruh variabel dalam setiap model memprediksi terjadinya obesitas.

Model 6 dinilai sebagai model yang cukup baik untuk menjelaskan hubungan perilaku sedentari dan obesitas dengan mengendalikan semua variabel luar. Besarnya koefisien determinan $\left(R^{2}\right)$ 14,97 yang berarti bahwa sekitar $14,97 \%$ kejadian obesitas pada siswa di Yogyakarta dan di Bantul dapat dijelaskan oleh faktor-faktor pada model 6 dan sisanya $85,03 \%$ dijelaskan oleh faktor lain. Obesitas terjadi karena multifaktor, tidak hanya aktivitas fisik sebagai penyebab langsung, tetapi juga terhadap asupan makan, genetik, kurang tidur (31), masalah fisiologis tubuh, dan faktor-faktor lainnya. Menurut suatu penelitian dilaporkan bahwa faktor-faktor risiko obesitas di antaranya aktivitas fisik kurang, asupan energi, asupan lemak $(7,17)$, selalu menggunakan kendaraan bermotor dan komputer, dan kebiasaan sarapan (11). Menurut penelitian di Spanyol, faktor-faktor yang dapat memprediksi kejadian obesitas di antaranya aktivitas sedentari, riwayat obesitas, menonton televisi, dan konsumsi minuman manis $(10,31)$.

\section{KESIMPULAN DAN SARAN}

Perilaku sedentari merupakan faktor risiko kejadian obesitas pada siswa di Yogyakarta dan Bantul yang memberi kontribusi sekitar 10,95\% dengan besarnya risiko 5,15 kali pada siswa dengan durasi sedentari yang lebih panjang. Terdapat perbedaan pola (durasi, jenis, dan frekuensi) aktivitas sedentari antara siswa obes dan tidak obes. Untuk perbedaan durasi aktivitas sedentari secara keseluruhan, siswa obes memiliki durasi yang lebih panjang dibandingkan dengan siswa tidak obes. Besar perbedaan rata-ratanya adalah 49,81 menit/hari. Berdasarkan jenis perilaku sedentari, siswa obes memiliki frekuensi untuk jenis aktivitas nonton tv, permainan papan dan kartu, serta duduk yang lebih sering dibandingkan siswa tidak obes. Berdasarkan jenis perilaku sedentari, siswa obes memiliki durasi untuk jenis aktivitas nonton tv, bermain game, bermain komputer, permainan papan dan kartu, serta duduk yang lebih lama dibandingkan siswa tidak obes.

Penelitian ini juga menunjukkan bahwa terdapat perbedaan pola (durasi, jenis, dan frekuensi) aktivitas sedentari antara siswa di Yogyakarta dan Bantul. Untuk perbedaan durasi aktivitas sedentari secara keseluruhan, siswa di Yogyakarta memiliki durasi yang lebih panjang dibandingkan dengan siswa di Bantul. Besar perbedaan rataratanya adalah 13,28 menit/hari. Berdasarkan jenis perilaku sedentari, siswa di Yogyakarta memiliki frekuensi untuk jenis aktivitas bermain game, komputer, dan penggunaan hp/tablet/ dan lain-lain yang lebih sering dibandingkan siswa di Bantul. Berdasarkan jenis perilaku sedentari, siswa di Yogyakarta memiliki durasi untuk jenis aktivitas bermain game, bermain komputer, penggunaan hp/tablet/dll, dan duduk yang lebih lama dibandingkan siswa di Bantul.
Sebaiknya orang tua dapat melakukan perubahanperubahan sederhana seperti anak misalnya dengan menetapkan peraturan untuk membatasi lama anak melakukan aktivitas berbasis layar dan mematikan tv selama makan malam. Anak-anak dibiasakan sejak dini menghindari kebiasaan minuman manis dan beralih ke air putih. Anakanak harus diberikan dukungan untuk beraktivitas di luar rumah dan menyarankan anak mengikuti aktivitas seperti program olahraga. Setelah melihat hasil penelitian ini bahwa pelajaran olahraga memiliki korelasi positif dengan obesitas maka sebaiknya pihak sekolah dapat menyusun suatu kurikulum atau kebijakan yang mendukung peningkatan jumlah pelajaran olahraga di sekolah ataupun dengan membuat program ekstrakurikuler khusus bidang olahraga dan mewajibkan anak-anak untuk mengikutinya.

\section{RUJUKAN}

1. IOTF. Available at: http://www.iotf.org/childhoodobesity. asp. Accessed January 2013.

2. World Health Organization. Obesity: Preventing and managing the global epidemic. WHO technical report seies 894. Geneva: World Health organization; 2000.

3. Whitaker RC, Wright JA, Pepe MS, Seidel KD, Dietz WH. Predicting obesity in young adulthood from childhood and parental obesity. The new England Journal of Medicine 1997; 13:869-73.

4. Ekelund U, Brage S, Froberg K, Harro M, Anderssen SA, Sardinha LB, et al. TV viewing and physical activity are independently associated with metabolic risk in children. The European Youth Heart Study 2006; 3:488.

5. Marti A, Moreno-Aliaga MJ, Hebebrand J, Martinez JA. Genes, lifestyles and obesity. Int J Obes Relat Metab Disord 2004; 28(3): 29-36.

6. Hadi $\mathrm{H}$. Beban ganda masalah gizi dan implikasinya terhadap kebijakan pembangungan kesehatan nasional. Pidato pengukuhan guru besar fakultas kedokteran UGM Yogyakarta; 2005.

7. Huriyati E. Aktivitas fisik pada remaja SLTP di Kota Yogyakarta dan Kabupaten Bantul serta hubungannya dengan kejadian obesitas. Yogyakarta: FK UGM; 2004.

8. Balitbangkes. Riset Kesehatan Dasar (Riskesdas) Laporan Nasional. Badan Penelitian dan Pengembangan Kesehatan Departemen Kesehatan. Jakarta: Departemen Kesehatan Republik Indonesia; 2007.

9. Balitbangkes. Riset Kesehatan Dasar (Riskesdas) Laporan Nasional. Badan Penelitian dan Pengembangan Kesehatan Departemen Kesehatan. Jakarta: Kementrian Kesehatan Republik Indonesia; 2010. 
10. Ochoa, Moreno-Aliaga, Gonzalez-Martinez, Martinez A, Marti A, GENOI members. Predictor factors for childhood obesity in a Spanish case-control study. Nutrition (Elsevier) 2007; 23:379-84.

11. Duncan S, Duncan EK, Fernandes RA, Buonani C, Bastos K, Segatto A, et al. Modifiable risk factors for overweight and obesity in children and adolescents from São Paulo, Brazil. BioMed Central Public Health 2011; 11:585.

12. McGinn, Theresa. Instruction for probability proportional to size sampling technique. RHRC Consortium Monitoring and Evaluation ToolKit 2004; 10:1-3.

13. Mariana R. Obesitas pada anak murid SD Kanisius Kurmosari 01 Semarang. Semarang: Laporan penelitian; 2010.

14. Arundhana Al, Thaha R, Jafar N. Aktivitas fisik dan asupan kalsium sebagai faktor risiko obesitas. Buletin Gizi Kita DIY 2012; 12(2): 68-80.

15. SPAN. Full report: chapter 6 . Sedentary behavior. NSW Schools Physical Activity and Nutrition Survey; 2004.

16. Gidlow C, Johnston LH, Crone D, Ellis N, James D. A systematic review of the relationship between socio-economic position and physical activity. Health Education Journal 2006; 65:338-67.

17. Purwaningrum DN, Hadi $\mathrm{H}$, Gunawan MA. Faktor risiko obesitas pada ibu rumah tangga miskin. Jurnal Gizi Klinik Indonesia 2012; 9(1): 1-9.

18. Rennie KL, Johnson L, Jebb SA. Behavioral determinants of obesity. Best Practice \& Research Clinical Endocrinology \& Metabolism 2005; 19(3): 343-58.

19. Hill JO, Peters JC, Wyatt HR. Using the energy gap to address obesity: A commentary. Journal of the American Dietetic Association 2009; 11:1848-53.

20. ASO. Fact and sheets: obesity and physical activity. Association for study of obesity. UK; 2012.

21. Dencker M, Thorsson O, Karlsson MK, Linden C, Wollmer P, Andersen LB. Daily physical activity related to aerobic fitness and body fat in an urban sample of children. The Journal of Pediatrics 2008; 149: 38-42.
22. Anderson SE, Economos CD, Must A. Active play and screen time in US children aged 4 to 11 years in relation to sociodemographic and weight status characteristics: A nationally representative cross-sectional analysis. BMC Public Health 2008; 8:366.

23. Trost SG, Kerr LM, Ward DS, Pate RR. Phyisical activity and determinant of physical activity in obese and non-obese children. International Journal of Obesity 2001; 25:822-9.

24. Pérez A, Hoelscher DM, Springer AE, Brown HS, Barroso CS, Kelder SH, et al. Physical activity, watching television, and the risk of obesity in students, Texas, 2004-2005. Preventing Chronic Disease 2011; $8(3)$.

25. Jafar N. Asosiasi faktor risiko gaya hidup dan sindroma metabolik pada berbagai tingkat sosial ekonomi. Jurnal Kesehatan Masyarakat Madani 2009; 2(4).

26. Caprio S, Daniels SR, Drewnowski A, Kaufman FR, Palinkas LA, Rosenbloom AL, et al. Influence of race, ethnicity, and culture on childhood obesity: Implications for prevention and treatment. Diabetes care 2008; 31(11): 2211-21.

27. Oliveira TC, Silva AA, Santos CJ, Silva JS, Conceicao SI. Physical activity and sedentary lifestyle among children from private and public schools in Northern Brazil. Rev Saude Publica 2010; 44(6): 1-8.

28. Mahdiah. Prevalensi obesitas dan hubungan konsumsi fast food dengan kejadian obesitas pada remaja SLTP kota dan desa di DIY. Yogyakarta: FK UGM; 2004.

29. US Dept of Labor, Bureau of Labor Statistics. American Time Use Survey. Available at: http://www.bls.gov/tus/ datafiles_2008.htm. Accessed July 3, 2013.

30. Crespo JC, Ellen S, Troiano RP, Barlett SJ, Macera CA, Anderssen RE. Television watching, energy intake, and obesity in US children: Result from the third National Health and Nutrition Examination survey, 1988-1994. Arch Pediatr Adolsc Med. 2001; 155: 360-5.

31. Foti KE, Eaton DK, Lowry R, McKnight-Ely LR. Sufficient sleep, physical activity, and sedentary behavior. Am J Prev Med 2011; 41(6): 596-602. 